\title{
TELJESKÖRÜ ISKOLAI EGÉSZSÉGFEJLESZTÉS (TIE): JELEN HELYZET
}

Szerző:

Somhegyi Annamária

Országos Gerincgyógyászati Központ
Lektorok:

Bálint Géza

Országos Reumatológiai

és Fizioterápiás Intézet

Falus András

Semmelweis Egyetem

Mező Ferenc

Debreceni Egyetem

Nemes Magdolna

Debreceni Egyetem
Szerző e-mail címe:

annamaria.somhegyi@bhc.hu
Somhegyi Annamária (2016): Teljeskörü iskolai egészségfejlesztés (TIE): jelen helyzet. Különleges Bánásmód, II. évf. 2016/4. szám, 61-80. DOI 10.18458/KB.2016.4.61

\begin{abstract}
Absztrakt
A magyar társadalom egészségi állapota elmarad attól, amit gazdasági fejlettsége lehetővé tenne. Ennek egyik legfontosabb oka az egészség-müveltségnek a rendkívül hiányos volta és az egészségtudatos életvezetés kellö elterjedtségének hiánya. A változtatás egyik fontos eszköze a köznevelési intézményekben történö hatékony beavatkozás, hiszen itt a gyermekekfiatalok sok-sok évet töltenek el, ami alatt a pedagógusok nevelö tevékenységének jelentös hatása van a gyermekek-fiatalok egészség-magatartásának alakulására is. Ezért rendkivüli jelentöségü az, hogy Magyarországon az egészségügy és az oktatásügy jól együtt tud dolgozni, és így 2012 óta elöírás a köznevelési intézmények részére a teljeskörü egészségfejlesztés. A közlemény bemutatja ennek indokoltságát, rövid lényegét, majd a kormányzati intézkedések által a pedagógusoknak nyújtott böséges segítséget és annak lelöhelyeit.
\end{abstract}

Kulcsszavak: iskolai egészségfejlesztés, ágazatközi együttmüködés, mindennapos testnevelés, pedagógiai módszerek, lelki egészség, egészség-ismeretek

Diszciplina: népegészségügy, egészségfejlesztés, pedagógia

\section{Abstract \\ HOLISTIC HEALTH PROMOTION (HHP): PRESENT SITUATION}

The health status of the Hungarian population is worse than that of other similarly developed countries' population. An important cause for this phenomenon can be characterized as high prevalence of unhealthy living and deficient health literacy. An important tool to change is an efficient health promotion in kindergarden and school. Children and young people spend many years in these institutions, and the way their teachers contact them will influence their health behaviour. Therefore it is highly important that 
holistic health promotion has been prescribed for all schools and kindergartens since 2012 in Hungary. Our paper presents reasonableness and a short summary of the holistic health promotion in educational institutions as well as the helping actions given for teachers by the government.

Keywords: school health promotion, intersectorial cooperation, daily physical education, pedagogical methods, mental health, health literacy

Disciplines: public health, health promotion, pedagogy

\section{Az iskolai egészségfejlesztés népegészségügyi nézőpontból}

Az Egészségügyi Világszervezet (EVSZ) évtizedek óta törekszik arra, hogy az egyes országok kormányai fokozott figyelmet fordítsanak az egészséget meghatározó társadalmi tényezőkre. Az EVSZ Európai Regionális Irodája az „Egészség 2020” kidolgozásával azt kívánta elősegíteni, hogy az egészségügyi rendszerek megerősítésén túl más szektorokat is megszólítson és bevonjon az ágazatközi együttműködésbe. A legtöbb egészségprobléma és a korai halálozás legföbb okai a társadalomban gyökereznek, melyeket a korai gyermekkori évek, az oktatás, a foglalkoztatás, a munkafeltételek, a jövedelmek, a környezet, a helyi körülmények, a társadalmi kirekesztés befolyásolnak (erről bővebben ld. a TIE-koncepciót, Net1). A lehetséges kiemelt cselekvési területek közt a kormányzati struktúrákban a horizontális megközelítés és az interszektoriális együttmüködés hangsúlyozandó. Az EVSZ és a magyar egészségügyi kormányzat az egészség egyenlőtlenségeket csökkentő ágazatközi szakpolitikák kidolgozásában müködik együtt (Pusztai, 2011). Nyilvánvaló, hogy a társadalom egészségi állapotának javítását célzó interszektoriális együttmüködés az oktatásügy részéről többek között abban nyilvánulhat meg, hogy az oktatásügy jogszabályai elvárásként tartalmazzák az egészségügy által megfogalmazott iskolai egészségfejlesztés tevékenységeit, az egészségügy pedig az iskolákat ennek megvalósításában segíti. Más módja az együttmüködésnek azon országok esetében, ahol az oktatást szabályozó jogszabályok nem tartalmaznak elegendően egyértelmü elvárásokat, hogy szakmai civil szervezetek ill. a népegészségügy intézményei ajánlásokat dolgoznak ki és segítő szolgáltatást nyújtanak (Net2, Net3).

A nemzetközi és a hazai népegészségügyi szakirodalom gazdagon bizonyítja az átfogó iskolai egészségfejlesztési programok, a tanulók lelki egészsége és tanulási eredményei közti szoros és oda-vissza müködő kapcsolatot.

Symons és tsai (1997) szakirodalmat áttekintő alap-közleményében az egészség és a tanulási eredmények számos összefüggésére hívja fel a figyelmet. Ezek közül a testmozgást érdemes külön kiemelni, mert sokan még ma sem hiszik el azt, amit a bizonyítékok mutatnak. A testmozgás és a tanulási eredményesség közötti kapcsolatra vonatkozó bizonyítékok azt mutatják, hogy a test-mozgásban résztvevők egyéb vonatkozású egészség-magatartása is jobb (kevesebb dohányzás, jobb táplálkozás, jobb stressz kezelés). A testmozgásban résztvevők társas kapcsolatai jobbak, jobb az iskolához füződő hozzáállásuk, ritkább a fáradtság, feszültség, szorongás, depresszió. A testmozgásban résztvevők tanulmányi eredményei jobbak, jobban tudnak koncentrálni, olvasni, írni, jobbak a matematikai eredményeik. Az iskolai testmozgás tanulási eredményességet és egészséget egyszerre javító hatása költséghatékony.

Az USA népegészségügyi központja, a „Centers for Disease Control and Prevention” (rövidítve CDC) honlapjának (Net4) adatai szerint az amerikai fiatalok tanulási 
eredményessége szorosan kapcsolódik az egészségi állapotukhoz. Az egészséget hátrányosan befolyásoló tényezők (pl. éhség, fizikai vagy érzelmi bántás, krónikus betegség) gyenge tanulási eredményességhez vezetnek. Az egészséget veszélyeztető magatartás-formák (dohányzás, kábítószer használat, erőszak, mozgás-szegény életmód) következetesen együtt járnak a tanulási eredményesség hiányával, és befolyásol-ják a tanuló hiányzását, osztályzatait, teszt-eredményeit és a koncentráció-képességet. A kapcsolat a másik irányban is igaz: a tanulási eredményesség a fiatal általános jól-létére vonatkozó fontos indikátor és a felnőttkori egészségi állapotra vonatkozó elsődleges meghatározó. A vezető nemzeti oktatási szervezetek felismerik az egészség és az oktatás közti szoros kapcsolatot, és annak szükségességét, hogy az egészséget minden tanuló részére az oktatási intézmény mindennapi müködésébe, az „oktatási környezetbe” építsék. (A honlapon található összefoglaló minden mondatához egy vagy több szakirodalmi hivatkozás tartozik.)

Az Egészséges Iskolák Európai Hálózatának (European Network of Health Promoting Schools) 1991-ben indult mozgalma Európa számos országában sikeres egészségfejlesztő tevékenységeket indított el sok iskolában. A munka kiindulópontja és alapfeltétele a tantestület elköteleződése a gyermekek egészségének javítása érdekében. Azt tapasztalták, hogy az iskolák akkor is foglalkozni kezdtek mindegyik fö egészség-kockázati tényezővel, ha eredetileg csak egyiket vagy másikat akarták kiemelni - ugyanis a fő egészség-kockázati tényezökre ható beavatkozások egymással kölcsönhatásban vannak. Pl. ha a túlsúlyt akarták eredetileg befolyásolni, nyilván mindjárt a testmozgást is befolyásolniuk kellett, de a lelki tényezők és az egészség-ismeretek is azonnal fontossá váltak. A szülők bevonódása a problémák felismerésébe és a kezelésüket szolgáló programok kialakításába alapvető tényezője a hatékonyságnak. Az európai hálózat 2002 évi koppenhágai értékelö konferenciáján úgy foglalták össze a 11 év alatt felgyülemlett nemzetközi tapasztalatok lényegét, hogy nem elegendő csupán a vállalkozó szellemű iskolákban projekt formájában végezni az iskolai egészségfejlesztést, hanem intézményesíteni is kell azt (Conference report, 2002).

Az EVSZ 2006-ban kiadott, iskolai egészségfejlesztésről szóló ajánlása (Stewart-Brown, 2006) hangsúlyozza, hogy azok az egészségfejlesztő programok hatékonyak, melyek hosszú távon müködnek, beépülnek az iskola mindennapjaiba és a fő egészség-kockázati tényezőkre hatnak. A kiadvány külön kiemeli, hogy a pusztán drogprevenciót (és egyéb szerfogyasztást) célzó, néhány alkalomból álló beavatkozások eredménytelenek.

Az Egészséges Iskolák Európai Hálózatának mai elnevezése: Iskolák az Egészségért (Schools for Health, rövidítve: SHE). A SHE mozgalom honlapján (Net5) bőségesen megtalálhatók különböző segítő anyagok azon iskolák részére, melyek az egészségfejlesztés terén fejlődni kívánnak. Ezek között szerepel egy összegző közlemény az iskolai egészségfejlesztés hatékonyságának bizonyítékairól. A közlemény 13.-16. oldalán találunk bőséges szakirodalmi hivatkozást arról, hogy az iskolai életbe beépülő azon tevékenységek bizonyultak leghatásosabbnak, melyek az egészséges táplálkozást, a rendszeres testmozgást és a lelki egészséget segítették elö. Különösen fontos, hogy a tanulók lelki egészségét elősegítő tevékenységek javítják a tanulók társas kapcsolatait és tanulmányi eredményeit, a mindennapos iskolai testmozgás pedig annak ellenére nem rontotta a tanulók tanulmányi eredményeit, hogy miatta kevesebb idő jutott a tanulásra (Young, St.Leger, Buijs, 2013, Net6).

A „National Association of School Psychologists” (USA) 2012-ben közzétett összefoglalása tömören idézi a tanulási eredmény és a lelki egészség közti kétirányú összefüggésről szóló legfontosabb bizonyítékokat (Net7). 
Shannon M. Suldo és tsai (2014) számos kutatás bizonyítékait gyüjtötték össze arra vonatkozóan, hogy a gyerekek lelki egészsége és tanulási eredményessége egymásra odavissza hatással van (Net8).

Az EVSZ Európai Irodája által kiadott „Health 2020” stratégiai dokumentum leszögezi, hogy a köznevelésnek és az egészségügynek végre együtt kell dolgoznia, mivel súlyos tudományos bizonyítékok mutatják, hogy az egészséget támogató nevelési környezet jobb tanulási eredményes-séget hoz, s a jobban tanuló gyermekek egészsége jobb (Net9).

A hazai szakirodalom részeként a Nemzeti Egészségfejlesztési Intézet 2006-ban megjelent kiadványa felsorolja és értékeli az iskolákban működő egészségfejlesztési programokat, majd úgy összegez, hogy a holisztikus megközelítésü iskolai egészségfejlesztés vezet eredményre, melyhez leginkább szemléletváltásra volna szükség (Fábián és Simich, 2006). Az Egészségügyi Minisztérium felkérésére készült el és 2006-ban jelent meg a pedagógusok részére korszerü egészségfejlesztési alapismereteket összefoglaló kötet (Barabás, 2006). Ez az iskolai egészség-fejlesztés olyan területeivel is foglalkozott, melyekre eddig kevéssé irányult figyelem. Paksi Borbála 2009-ben készült kutatási beszámolójában (Paksi, 2009) arról tudósít, hogy az iskolák egyre nagyobb hányada szervez prevenciós programokat. Ezek főleg ismeretátadást tartalmaznak, mégis az utóbbi 5 évben egyre nagyobb arányban a tanulók személyiségfejlesztését is célozzák, bár az alkalmazott óraszámok és a többnyire külső szolgáltatók nem tesznek lehetővé holisztikus megközelítést. A szerző megállapítja, hogy a pedagógusok szerepfelfogásában kevéssé hangsú-lyosan vannak jelen a nevelési feladatok, mégpedig a magasabb évfolyamokon még kevésbé, mint az alacsonyabbakon. Benkő Zsuzsanna a Népegészségügy hasábjain 2010-ben tekintette át az egészségfejlesztés helyzetét a közoktatásban: hiányolja a holisztikus, multidisciplinaris iskolai egészségfejlesztés megvalósításához szükséges feltételeket, és úgy látja, hogy az egészségfejlesztés közoktatásba integrálása a közoktatás szükségszerủ átalakításával képzelhető el, s „ezekhez a változásokhoz az egész nemzetre szükség van" (Benkő, 2010). Somhegyi 2012-ben elemezte a nemzeti köznevelésről szóló 2011. évi CXC törvényt abból a szempontból, hogy az mennyire segíti elő a pedagógusok egészségfejlesztő munkáját az iskolák mindennapjaiban (Somhegyi, 2012).

A szakirodalomból kitünik, hogy az iskolai egészségfejlesztés akkor hatékony, ha teljes körü (holisztikus). Ez az alábbiak teljesülését jelenti:

1. nem szükül le egyik-másik beavatkozási területre, hanem mindegyik fő egészségkockázati tényezőt befolyásolja;

2. nem szükül le egy-egy akció időtartamára, hanem az iskola mindennapi életében folyamatosan és rendszeresen jelen van;

3. nem szükül le egy iskolai közösség valamelyik részére, hanem az egészségfejlesztést megvalósító iskola minden tanulója részt vesz benne;

4. nem szükül le a tantestület egyes tagjaira, hanem a teljes tantestület és az iskola dolgozói közössége részt vesz benne; és

5. nem szükül le az iskolán belüli közösségre, hanem bevonja a szülöket és az iskola közelében müködő, erre alkalmas civil szervezeteket, valamint az iskola társadalmi környezetét (pl. fenntartó) is.

A teljeskörü iskolai egészségfejlesztés az idevágó nemzetközi és hazai szakirodalom bizonyítékai szerint az alábbi részterületeken jelentkező hatások révén eredményezi a jobb egészséget:

- a tanulási eredményesség javítása;

- az iskolai lemorzsolódás csökkenése;

- a társadalmi befogadás és esélyegyenlőség elősegítése; 
- a dohányzás, az alkoholfogyasztás, a kábítószer-fogyasztás és egyéb szenvedélyek elsődleges megelözése;

- bünmegelőzés;

- a társadalmi kapcsolatok javulása a kortársakkal, szülőkkel, pedagógusokkal;

- az önismeret és önbizalom javulása;

- az alkalmazkodó készség, a stressz kezelés, a problémamegoldás javulása;

- érett, autonóm személyiség kialakulása;

- a krónikus, nem fertőző megbetegedések (lelki betegségek, szív-érrendszeri, mozgásszervi és daganatos betegségek) elsődleges megelözése;

- a társadalmi tőke növelése.

\section{A teljeskörü iskolai egészségfejlesztés (TIE) rövid összefoglalása}

A fenti szakmai alapokon nyugodva, a 46/2003 (IV.16.) OGY határozatnak megfelelően, a Nemzeti Népegészségügyi Program részeként, az 1066/2001 (VII.10.) kormányhatározattal létrehozott Népegészségügyi Tárcaközi Bizottság 2003. május 22-i, 2003. november 11-i és 2004. március 2-i üléseinek döntései értelmében az Egészségügyi Minisztérium az illetékes tárcákkal (Oktatási Minisztérium, Gyermek-, Ifjúsági- és Sport Minisztérium, Pénzügyminisztérium) és rendkívül széles szakmai együttmüködéssel megtervezte a teljeskörü iskolai egészségfejlesztési programot, akkori nevén az „,iskolai egészségfejlesztési normatíva" tervét (a munka azóta is hüséges kézbentartója e sorok szerzője volt).

A teljeskörü iskolai egészségfejlesztés (rövidítve: TIE) az alábbi négy egészségfejlesztési alapfeladat rendszeres végzését jelenti - minden tanulóval, a teljes tantestület és alkalmazotti közösség, az iskolaegészségügyi szolgálat szakemberei, a szülők és az iskola környezetének bevonásával, szakmai ellenőrzés és segítés mellett:

I. Egészséges táplálkozás megvalósítása - lehetőleg az EVSZ 2001. évi ajánlása (Net10) szerint a helyi termelés és a helyi fogyasztás összekapcsolásával;

II. Mindennapos testnevelés minden tanulónak az egészségfejlesztési kritériumok teljesítésével - ennek részeként sok más szakmai elvárás közt jól végzett tartásjavító torna, relaxáció, tánc és sport is; valamint a testnevelés órákat kiegészítő egyéb testmozgás;

III. A gyermekek érett személyiséggé válásának azaz lelki egészségének elösegítése személyközpontú pedagógiai módszerekkel és a müvészetek személyiségfejlesztő hatékonyságú alkalmazásával (ének, tánc, rajz, mesemondás, népi játékok és népi rítusjátékok, kézmüvesség, stb.);

IV. Egészségismeretek széles köre készség szintű elsajátításának elősegítése (ezen belül baleset-megelőzés és elsősegélynyújtás; személyi higiéné; a szenvedélybetegség kialakulásához vezető szerek fogyasztásának, valamint a gyermeket, tanulót veszélyeztető bántalmazásnak a megelőzése is). A részletes témalistát a TIE ajánlás tartalmazza (ld. alább).

\section{A TIE megvalósításának rövid története}

Fentiek alapján a teljes körü iskolai egészségfejlesztés megvalósítása népegészségügyi, pedagógiai és össztársadalmi cél (Somhegyi 2006, 2009, 2010).

A teljeskörü iskolai egészségfejlesztés tervének elkészülte, azaz 2003 óta hét éven át nem volt kellő kormányzati akarat és/vagy forrás arra, hogy a fokozatos elterjesztés megkezdődhessen. A népegészségügyi célokért elkötelezett szakmai mühelyek közös erőfeszítése nyomán azonban számos iskola szándékozott a TÁMOP 6.1.2./A/09/1 pályázati 
kiírására pályázni a teljeskörü iskolai egészségfejlesztés bevezetése érdekében, végül az elektronikus pályázatírás technikai nehézségeit 26 iskola vállalta. A beadott 26 pályázatból egyetlen egy debreceni iskola nyert, a többiek pályázatát értelmetlen formai hibákra hivatkozva elutasították (a szakmai része mindegyik pályázatnak megfelelő volt).

A „Mester és Tanítvány” címü pedagógiai folyóirat 2006. januári száma közölte Hoffmann Rózsa oktatási programját (Hoffmann, 2006), melyben e sorok írójának tollából szerepelt a teljeskörü iskolai egészségfejlesztés fokozatos elterjesztése; majd a Barankovics István Alapítvány 2009-ben megjelent, köznevelést-közoktatást elemző, összefoglaló kiadványában Hoffmann Rózsa a köz-oktatás első prioritásának a következőt nevezi meg: „Teljes ember nevelése erkölcsre, tudásra, egészségre” (Hoffmann, 2009). 2009. decemberben jelent meg Sólyom László köztársasági elnök úr kezdeményezésére a „Szárny és teher” címü kiadvány (Csermely és tsai, 2009), mely a közoktatás-nevelés rendszerszerü jobbítását az ország előtt álló egyik legfontosabb kihívásként járja körül. A közoktatás gyengeségei között felsorolja az egészségnevelés méltatlanul alacsony megbecsültségét és szintjét, és a közoktatás jobbítását célzó elsőrendü javaslatai között az egészséges életmódra nevelést, az egészségfejlesztést nevesíti, említve, hogy ez az egészséges táplálkozást, a mindennapi testmozgást, a lelki egészséget is magában foglalja.

A 2010. júniusban felállt kormány kormányprogramjában szerepeltette az „erkölcsre, tudásra, egészségre nevelést", valamint a mindennapi testnevelés felmenő rendszerü bevezetését külön nevesítve is (Net11). Az Emberi Erőforrások Minisztériuma (EMMI) a teljeskörü iskolai egészségfejlesztés bevezetését előbb nagyszabású, a TÁMOP 3. és TÁMOP 6. közös forrásain alapuló pályázatkiírással kívánta elősegíteni - a Kormány az akcióterv fenti tartalmú módosítását a 1276/2011 (VIII.10.) Korm. határozattal jóváhagyta -, azonban az ezt követően szükségessé vált forrás-átcsoportosítás miatt végül erre mégsem került sor. A projektszerü elindítás helyett azonban a kormányzat a köznevelés egészébe történő beépítést valósította meg az idevonatkozó jogszabályok megfelelö kialakításával:

1. A nemzeti köznevelésről szóló 2011. évi CXC. törvény egésze a nevelést állítja középpontba, mégpedig a gyermek testi-lelki egészségének elősegítésével, amit a törvény számos paragrafusa bizonyít (pl. a gyermeki jogok és kötelességek együttese, a gyermeknek megfelelö bánásmód, a szülök és az iskola együttmüködése, az erkölcsi és a hazafias nevelés, a családi életre nevelés, az egészségnevelés és környezeti nevelés). A törvény tartalmazza a mindennapos testnevelést /27.§.(11)/ minden évfolyam részére, melynek felmenő rendszerü megvalósítása a 2015/16-os tanévben vált teljessé. /97.§.(6)/.

2. A nevelési-oktatási intézmények müködéséröl és a köznevelési intézmények névhasználatáról szóló 20/2012 (VIII. 31.) EMMI rendelet (továbbiakban rövidítve: 20/2012-es EMMI rendelet) X. fejezete foglalkozik a tanulók egészségével, biztonságával kapcsolatos feladatokkal: a nevelési-oktatási intézmény teljes körü egészségfejlesztéssel kapcsolatos feladatait koordinált, nyomon követhető és mérhető, értékelhető módon kell megtervezni a helyi pedagógiai program részét képező egészségfejlesztési program keretében. Ezt a programot a nevelötestületnek kell elkészítenie, az iskola-egészségügyi szolgálat közremüködésével.

3. A közétkeztetésre vonatkozó táplálkozás-egészségügyi elöírásokról szóló 37/2014. (IV.30) EMMI rendelet megjelenése és hatályba lépése 2015. szeptember 1-jétől nagyban segíti az egészséges táplálkozás korszerü elvárásainak teljesülését, miközben a helyi termékek felhasználását is hangsúlyozza.

4. A nemdohányzók védelméről és a dohánytermékek fogyasztásának, forgalmazásának egyes szabályairól szóló, 1999. évi XLII. törvény 2011-ben történt szigorítása jelentősen támogatja az iskolai egészségfejlesztés megvalósulását. 
5. Az iskolaegészségügy segítő szerepéről az egészségügyről szóló 1997. évi CLIV. törvény 42.§.1. bekezdése, az egészségügyi alapellátásról szóló 2015. évi CXXIII. törvény és az iskola-egészségügyi ellátásról szóló 26/1997. (IX.3.) NM rendelet, valamint az egészségügyről szóló egészségbiztosítás keretében igénybe vehető betegségek megelőzését és korai felismerését szolgáló egészségügyi szolgáltatásokról és a szürővizsgálatok igazolásáról szóló 51/1997. (XII.18.) NM rendelet is rendelkezik.

Vagyis a teljeskörü iskolai egészségfejlesztés rendszerszerü megvalósítását jelenleg jogszabályok írják elő. Annak érdekében, hogy a törvényekben és rendeletekben megfogalmazott szép és jó elvárások meg is valósuljanak, az egészségügy részéről még sok tennivaló van: pl. a mindennapos testnevelésről a szülőket és tanulókat is jól kell tájékoztatnunk, hogy megérezzék hasznos voltát és így a tanulók kellő indítékkal vegyenek részt benne, ne papíron létező igazolásokkal és fölösleges felmentésekkel bújjanak ki alóla; a köznevelési intézmények részére segítséget kell nyújtanunk egészségnevelési-egészségfejlesztési tevékenységeikhez, valamint ezek nyomon követését is biztosítanunk szükséges.

\section{A teljeskörü iskolai egészségfejlesztés ágazatközi segítése projektek útján}

A TIE minél eredményesebb megvalósítását 2012-2014 közt három jelentős TÁMOPprojekt segítette. Mindhárom projekt eredményeinek linkjét tartalmazza a pedagógusok munkájának segítését célzó TIE ajánlás (ld. alább).

TÁMOP-6.1.1.-12/1-213-001 „Egészségfejlesztési szakmai hálózat kialakitása” kiemelt projekt köznevelési alprojekt:

A projektben szakértők széles együttmüködésében az alábbi segítő szakmai anyagok készültek el:

11 db elméleti anyag, melyek legtöbbjét a téma iránt leginkább érdeklődő pedagógusok, vezetők forgathatják haszonnal. Ezek közt szerepel:

- $\quad$ az iskola TIE-munkájának belső nyomonkövetésére, értékelésére szolgáló kérdőív

- a NAT és a kerettantervek TIE tartalmainak bemutatása

- az egészségtudatos munkahellyé váló iskola

- nemzetközi és hazai jó példák bemutatása

- a TIE nyomonkövetésére alkalmas mutatók bemutatása

- Anglia, Finnország és Kalifornia iskolai egészségfejlesztési gyakorlata.

$7 \mathrm{db}$ irányelv az egészség-ismereti témalista 7 eleméhez (az ezekben írtak fontos tudnivalókat tartalmaznak a mélyebben érdeklődő pedagógusok részére):

- Táplálkozás

- Testmozgás

- Személyi higiéne

- Baleset- és sérülés-megelőzés

- Iskolai erőszak megelőzése

- Pszichoszexuális nevelés

- Szenvedélybetegségek megelőzése vagy drogprevenció (még nincs készen)

$6 \mathrm{db}$ mintaprogram az egészség-ismereti témalista 6 eleméhez (ezekben konkrét programszerü tevékenységeket talál a gyakorló pedagógus, melyeket a mindennapi munkájában jól használhat, de a saját iskola helyzetének megfelelően természetesen módosítva is felhasználhatók):

- Táplálkozás 
- Testmozgás

- Baleset-megelőzés, elsősegélynyújtás

- Lelki egészség

- Pszichoszexuális nevelés

- Szerfogyasztás megelözése

TÁMOP-6.1.2.A-14/1-2014-0001 „Komplex intézményei mozgásprogramok és kapcsolódó egészségfejlesztési alprogramok megvalósítása az általános iskolákban, többcélú intézményekben, valamint szabadidős közösségi mozgásprogramok és kapcsolódó egészségfejlesztési alprogramok megvalósítása az iskolán kívüli szereplök bevonásával" kiemelt projekt:

A projektben a Klebelsberg Intézményfenntartó Központ (KLIK) által kiválasztott 288 iskolában valósítottak meg különböző egészségfejlesztési programelemeket. Ehhez minden megyében ill. minden résztvevő iskolában koordináló tanárok adtak szervezési segítséget, őket a Nemzeti Egészségfejlesztési Intézet (NEFI) munkatársai továbbképzési napokon készítették fel feladataikra. Az iskolai egészségfejlesztési programelemeket megyénként szervezett nagy rendezvények egészítették ki: a Hétpróbák. Ezeken a gyerekek különbözö érdekes, rendhagyó mozgásprogramokban vehettek részt, s a tapasztalat szerint ezek a rendezvények rendkívül eredményesek voltak: a gyerekek, a pedagógusok, de még a szülök szívét is megérintették ezek a valódi közösségi élmények.

A projektben az alábbi szakmai segítő anyagok készültek:

- TIE Koncepció: a TIE szükségességének bőséges háttere és az egyes ágazatok által nyújtható segítségek.

- 10 db ún. EPSZA (Egészségfejlesztési Programelem Szakmai Ajánlás) füzet egyes egészség-ismereti témákban ill. a testnevelés órán kívüli testmozgás segítésére: ezekben is jól használható konkrét tevékenységek szerepelnek, melyeket a pedagógusok saját iskolájuk helyzetéhez illően módosítva is használhatnak.

- $2 \mathrm{db}$ részletes háttér- és módszertani anyag táplálkozás és testmozgás témában.

- 10 db ,„példamutató” kisfilm az egészségmagatartás alakítása érdekében.

A TÁMOP-3.1.13-12-2013-0001 „A testnevelés új stratégiájának és fizikai állapot mérési rendszerének kialakitása és az önkéntes részvétel ösztönzése a komplex iskolai testmozgásprogramok szervezésében” kiemelt projekt:

A teljeskörü iskolai egészségfejlesztés egyik tevékenységének, a mindennapos testnevelésnek az eredményes, vagyis az egészségfejlesztési kritériumoknak megfelelő megvalósításához nyújtott segítséget a testnevelő pedagógusoknak és iskoláknak, ezen belül több más tevékenység mellett kb. 8000 testnevelőt részesített szemléletformáló céllal 30 órás továbbképzésben, az egységes országos fizikai fittségmérés eszközeit és 7 szemléletformáló módszertani kiadványt eljuttatott minden iskolába.

A kiadványok rendkívül gyakorlatiasak, a mindennapos testnevelés módszertani megújulását segítik. Összefoglalásuk az alábbi:

- Alternatív játékok a mindennapos testneveléshez, testmozgáshoz: Ebben a kiadványban 87 féle hasznos, értelmes és a gyerekek számára élvezetes játék szerepel, melyet a tornatermen kívüli testnevelés órán alkalmazni lehet.

- A taktikai gondolkodás fejlesztésének lehetöségei a játékoktatásban:E kiadványban különösen értékesnek tartjuk, hogy megmutatja, hogyan fejleszthető játékok útján az olyannyira szükséges testtudat, a térbeli tájékozódás (vigyázat: az autóvezetéshez alapszükséglet, mégis a mai gyerekek e téren rosszul állnak, valószínüleg a mozgásszegénység, a mozgásos tapasztalatok hiánya és a számítógépes tevékenységek 
túltengése miatt), a társas kapcsolatok, az eszközökkel kapcsolatos tudatosság, az energiabefektetés tudatossága.

- Mozgásfejlesztés, ügyességfejlesztés mozgáskoncepciós megközelítésben: E kiadványban ahhoz kap gyakorlatias segítséget a testnevelö, hogy az eltérö testi adottságú tanulók részére is, mindegyiküknek a megfelelő fejlesztő mozgástevékenységet alkalmazhassa, és így mindegyik tanuló átélhesse a jól végzett munka örömét: saját ügyességének fejlődését. Ez nemcsak a testi-lelki egészséghez szükséges, de az idegrendszer fejlődésének is eszköze, ezért a tanulási eredményességet is segíti.

- Jógaalapú mozgásprogram: Azon testnevelők, akikhez a jóga közel áll, haszonnal forgathatják ezt a kiadványt: a jógagyakorlatok a testtudatot, izomtudatot fejleszthetik, és hozzájárulhatnak (bár nem helyettesítik) a hatékony tartásjavításhoz.

- Stressz-kezelés és relaxáció alkalmazása a testnevelésben: Mai világunkban már a gyermekkorban is jelen van a feloldatlan stressz-terhelés, ami az oly gyakori pszichoszomatikus (azaz lelki eredetű testi) betegségek egyik előidézője. Ezért a lelki egészségfejlesztés egyik fontos eszköze a stressz-oldás, a relaxáció. E kiadvány a relaxáció testnevelésben végezhető egyszerü módszereit mutatja be.

- Tánc és kreatív mozgás: E kiadvány nem tánctanításról szól, csak annak előkészítéséröl, melyet a testnevelési órába haszonnal építhet be a pedagógus, ha ezt közel állónak érzi. A néptánc ill. társastánc testnevelésben történő alkalmazásához ennél többre lenne szüksége a pedagógusnak, de hasznos és értékes segítséget talál a kiadvány gyakorlataiban, melyeket a kisebbek-nagyobbak részére is alkalmazhat.

- Egészség-és személyiségfejlesztö kézikönyv az iskolai testneveléshez: A kiadvány a testnevelő személyiségfejlesztő munkáját kívánja tudatosabbá, eredményesebbé tenni, mivel tudott: a test, a lélek és a szellem nem müködhet egészségesen egymás nélkül. Ez a személyiségfejlesztés természetesen a minőségi testnevelés keretébe ágyazottan jelenik meg, és a következő lényeges fejlesztési területeket öleli át: széles körü mozgásműveltség; rendszeres fizikai aktivitás; egészségtudatos magatartás; fejlett önismeret és együttműködésre kész attitüd; felelősségteljes magatartás; problémamegoldó, konstruktív gondolkodás.

A kiadványok közül legizgalmasabbnak a tornatermen kívül játszható, a testnevelés céljait tekintve hasznos és érdekes játékokat bemutató kiadványt tekinthetjük, hiszen napjainkban még nincs minden iskolában annyi tornaterem, hogy minden osztály minden testnevelési órát ott tarthassák meg. Ez nem is baj, hiszen jóval változatosabb, kreatívabb megoldások születhetnek, mint a tornatermi órák megszokott programja.

\section{A teljeskörü iskolai egészségfejlesztés ágazatközi segítése a TIE ajánlás útján}

A teljeskörü iskolai egészségfejlesztés minél eredményesebb megvalósítása érdekében az Oktatásért Felelős Államtitkárság és az Egészségügyért Felelős Államtitkárság - jelen sorok szerzőjének közreműködésével - 2016 tavaszán elkészítette a pedagógusok munkájának segítésére a TIE ajánlást, melyben röviden összefoglaltuk, hogy a TIE mit is jelent az iskolák mindennapjaiban, valamint a mindennapi iskolai életben végzendő 4 alaptevékenységhez összegyüjtöttük a fellelhető és javasolható szakmai segítségeket - természetesen a mai kornak megfelelően elektronikus linkek, honlapok formájában.

A TIE ajánlást az Oktatási Hivatal $(\mathrm{OH})$ 2016. április 19-én elküldte minden iskola igazgatójának (a címben itt az iskolák vannak írva, de a szövegben hangsúlyozzuk, hogy az 
óvodák és kollégiumok a megfelelő módosításokkal alkalmazhatják ugyanezen ajánlást). A TIE ajánlás elérhető a kormányzati honlapon (Net12).

Alább kiemelem a TIE ajánlásból a legfontosabb részeket (az alább megadott honlapok a TIE ajánlás kiküldése előtt, azaz 2016. márciusban ellenőrizve voltak és megnyíltak):

i. Egészséges táplálkozás segítése, lehetöleg a helyi termelés-helyi fogyasztás összekapcsolásával:

Nyilvánvaló, hogy az iskolában nem a pedagógus főzi az ebédet és nem ő állítja össze a büfé választékát. Ahhoz azonban, hogy a gyerekek értsék és elfogadják, sőt szívükbe zárják az egész-séges táplálékot ill. táplálkozást, ahhoz nem elég a közétkeztetési rendelet szerinti kínálat nyújtása. Ahhoz sok-sok jó pedagógiai ötlet felhasználásával foglalkozni kell a gyerekekkel, rá kell őket vezetni, hogy miért jó és fontos az egészséges táplálék és kik húznak hasznot a széleskörüen divatba jött egészségtelen táplálékokból. A gyerek nem szereti, ha bolondnak nézik és kihasználják, tehát ezt az egészség rovására hasznot húzó jelleget nagyon érdemes kidomborítani a gyerekek (meg a szülők) előtt. Az újszerü étkeket meg is kell ismertetni: miből készült, az alapanyaga hogyan néz ki, hol lehet ilyet találni a természetben, hol termesztik vagy nevelik, hol lehet megvenni, ha otthon is fel akarják használni, hogyan készül belöle az adott étel, milyen elönyös hatása van az egészségre, ha megesszük. A megismerés fontos módja a kóstoltatás is: érdemes kialakítani ennek módját, lehetőségét akár a menzán is. Mindez az egészség szolgálatán kívül azért is fontos, hogy ne a szemétbe menjen a sok drága étel! Főleg most, amikor egyre több gyerek étkezik ingyenesen, vagyis az adófizetők pénzén, jó odafigyelnünk a pocsékolás megelőzésére.

A helyi termelés-helyi fogyasztás összekapcsolását az Egészségügyi Világszervezet már 2001-ben ajánlotta, mivel a távolról szállított élelmiszereknél jóval egészségesebbek a helyiek: frissebbek, kevesebb vegyszerre szorulnak, idényben fogyaszthatók, a környezetet kímélik, és nem mellékesen a helyben élöknek adnak munkát. Ezeket a szempontokat fontos figyelembe vennie mindenkinek, így az a pedagógus, aki ezt alkalmazza maga is és erre neveli a gyerekeket (szüleiket is), társadalmilag igen hasznos munkát végez.

Az egészséges táplálkozással kapcsolatban a legfontosabb segítséget a Magyar Dietetikusok Országos Szövetsége honlapján lehet megtalálni: www.mdosz.hu.

Ezen kívül a www.egeszseg.hu honlapon a TIE anyagait érdemes megkeresni: ezekben is sok ötletes, gyakorlatias segítség van.

ii. Mindennapos testnevelés az egészségfejlesztési kritériumok teljesitésével, és az azt kiegészítö testmozgás:

A mindennapos testnevelés törvényi elöírása az egyik legfontosabb népegészségügyi beavatkozás, mert a legtöbb civilizációs népbetegség megelőzésének egyik fő eszköze, melyet az EVSZ is sok éve szorgalmaz (Net12). Ezen kívül jó hír a pedagógusoknak, szülőknek, sőt a gyerekeknek, hogy a tanulási eredményességet is javítja! Ahhoz azonban, hogy ezeket a kívánatos hatásokat valóban hozza is a mindennapos testnevelés, nem mindegy, hogyan müködik. A mindennapos testnevelés preventív hatásaiban érintett orvosi szakmai társaságok 2012-ben összeállították azokat az egészségfejlesztési kritériumokat (Somhegyi, 2014), melyeknek teljesülniük kell ahhoz, hogy a mindennapos testnevelés várt egészséghatásai bekövetkezzenek. Ezek lényege címszavakban:

- Minden nap minden tanuló aktív részvételével valósul meg (kapcsolat a szülőkkel annak érdekben, hogy az indokolatlan felmentések visszaszoruljanak).

- Minden alkalommal megfelelő keringési- és légzőrendszeri terhelés (kipirulás, izzadás, lihegés a jele). 
- Minden alkalommal a jól végzett munka és a játék siker- és örömélménye minden tanulónak (ehhez müvészi pedagógiai módszerek szükségesek a testnevelők részéről!).

- Megfelelő mozgás az eltérő testi adottságú gyermekeknek is.

- A közösségi mozgásélmény jelentőségének hangsúlyozása a versenyszellem erösítése helyett.

- Minden testnevelés órán gimnasztika, benne minden tanulóval a biomechanikailag helyes testtartást kialakító, automatizáló és fenntartó speciális tartásjavító torna az izomérzésekre, a testtudat kialakítására is ügyelve (Somhegyi és tsai 2005, valamint Net13), lábizomerősítés, légzéstechnika.

- Stresszoldás.

- Tánc, melyen belül elönyben részesítendő a néptánc és társastánc (Ezeknek speciális hatásaik vannak a lelki egészségre: a fiú-lány szerep különbözőségére tanítanak szavak nélkül; valamint a néptánc még a hagyományokhoz kötődést is elősegíti; mindkét hatás lényeges összetevője a lelki egészségnek).

- Diáksport.

- Életmód sportok elsajátítása (Az életmód-sport kifejezés Monspart Saroltától származik. Az ilyen sportot akár egy életen át is lehet csinálni, mert az átlagos ember számára a hozzá szükséges feltételek általában adottak. Tehát pl. az úszás, biciklizés, futás, focizás ilyen, míg pl. a síelés, vitorlázás nem ilyen).

- Egészségismeretek hatékony átadása a megtapasztalt élettani hatások tudatosításával.

- Értékelés módja a részvételre serkent.

- Tornatermen kívül is hatékony testnevelés óra.

E szempontok szerencsére nem idegenek a testnevelőkre vonatkozó jogszabályi elöírásoktól: mind a NAT, mind a kerettantervek tartalmazzák ezeket. A Magyar Diáksport Szövetség TÁMOP-projektjében is ezekre hívták fel a figyelmét annak a kb. 8000 testnevelőnek, aki a továbbképzéseken részt vett. A kiadványaik közül kiemelkedő az, amelyben a tornatermen kívüli testnevelés órákon alkalmazható 87 féle, érdekes és hasznos mozgásos játékot mutatnak be: így már nem kérdés, hogy mit is lehet kezdeni, ha nincs elég tornaterem. E 87 féle játékon kívül minden iskolának, pedagógusnak megvannak a saját kreatív ötletei is, hogy saját lehetőségeiket kihasználják. Azt szükséges látnunk, hogy a gyerekeknek mozgásra van szükségük minden nap, nem tornateremre!

Az Egészségügyi Világszervezet ajánlása gyermek és fiatalkorban napi 60 perc testmozgás: erre számos korábbi dokumentumot követően a 2015-ben készült „Physical activity strategy for the WHO European Region 2016-2025" is nyomatékosan hívja fel a figyelmet (Net12). Ezt még a mindennapos testnevelés sem képes megadni, tehát emellett még oda kell figyelni az iskolában és a családban, hogy a gyerekek testnevelés órán kívül is mozogjanak, s hétvégén lehetőleg a család együtt menjen valamilyen mozgásprogramra (pl. kirándulni, úszni, sétálni, futni, biciklizni).

A mindennapos testneveléshez leghasznosabb linkek:

www.mdsz.hu

ezen belül „Alternatív játékok”:

http://www.mdsz.hu/tesi/tesim-kiadvanyok/

www.gerinces.hu

ezen belül szülők tájékoztatására:

http://gerinces.hu/prevencio/mindennapi-testneveles-hatekony-mukodese-orvosoktolszuloknek/

a hatékony tartásjavításra: 
http://gerinces.hu/prevencio/tartaskorrekcio-konyv-es-dvd-csak-gerincesen/

A mindennapos testnevelést kiegészítő testmozgáshoz leghasznosabb link:

www.egeszseg.hu

ezen belül különösen:

- Mindennapos testmozgás - módszertani szakanyag.pdf

- Mindennapos testmozgás - mellékletek.pdf

- 7_TIE_EPSZA_Spuri_a_suliba_2015_11.pdf

- 8_TIE_EPSZA_Lepeselonyben_2015_11.pdf

- 9_TIE_EPSZA_Delutani_szabadido2015_11.pdf

- 10_TIE_EPSZA_Sportos_iskolai_rendezveny_2015_11.pdf

- A mindennapos testnevelés, testmozgás

- A rendszeres testmozgást és a testmozgás iránti igény kialakítását célzó iskolai egészségfejlesztési program, beleértve a tanórai és tanórán kívüli egészségfejlesztési tevékenységeket. A helyes testtartás kialakítását támogató program.

iii. A lelki egészség elösegítése személyközpontú pedagógiai módszerekkel, valamint a müvészetek (ének, tánc, rajz, mesemondás, népi játékok és népi rítusjátékok, kézmüvesség, stb.) személyiségfejlesztö hatékonyságú alkalmazásával:

A pedagógusok legfőbb eszköze a tanulók személyiségének megfelelő fejlesztésére és ezzel a lelki egészségük segítésére az a bánásmód, ahogyan nap mint nap szólnak hozzájuk, néznek rájuk, és ahogyan a tudnivalókat tanítják. A pedagógus egész lénye és minden megnyilvánulása folyamatosan hat a tanulók lelki egészségére, személyiségfejlődésére. Azokat a pedagógiai módszereket, melyeket a pedagógusoknak különösen figyelmébe ajánlunk, személyközpontú pedagógiai módszerek címszóval foglaljuk össze. Ezeket, vagy ezek közül többet a pedagógus-társadalom már megismerhetett a különböző pedagógustovábbképző programokból, így feltehetőleg minden tantestületben vannak olyan pedagógusok, akik a többieknek e téren segítséget tudnak nyújtani.

Személyközpontú pedagógiai módszerek például (a lista a teljesség igénye nélkül készült):

- a Mentálhigiénés Alapprogramban megismert módszerek (Rogers-i személyközpontúság)

- kooperatív tanulási módszerek

- interaktív tanítás-tanulás

- epochalis oktatás

- projekt-szerü oktatás

- Komplex Instrukciós Program módszerei

A lelki egészségben történö nevelést a pedagógusok leginkább akkor tudják mindegyik tanulójuk számára nyújtani (márpedig erre van szükség), ha az egész tantestület együttmüködik e téren. Ehhez azt javasoljuk, hogy a tantestület egésze tanácskozzon erről: közösen keressék meg, milyen módszereket ismernek már az egyes pedagógusok, és hogyan lehetne ezek alkalmazását az egész tantestületre - és így minden tanulóra - kiterjeszteni. E munkában az iskola-vezetésnek az osztályfőnökök munkáját különösen támogatnia kell.

Ha a tantestület megtervezte, mit fog tenni, akkor avassa be terveibe a tanulókat és a szülőket is: keltse fel az érdeklődésüket, mert így támogató légkört tudnak kialakítani, s ez fontos az elérni kívánt hatás szempontjából. 
A problémás gyermekekkel és helyzetekkel történő foglalkozás módját az iskola szabályzataiban helyes rögzíteni, ebben az iskola-egészségügy és az iskola-pszichológus sokat tud segíteni, de az iskolai szociális segítő és más szakemberek bevonása is szükséges lehet.

\section{Müvészetek alkalmazása:}

A pedagógusok személyközpontú pedagógiai munkáját rendkívüli módon megkönnyíti, ha használják a müvészetek léleknemesítő-gyermekszelídítő, valamint tanulást és kreativitást serkentő hatását, azaz az érzelmi és értelmi életre gyakorolt hatását. Ehhez alapvetően kétféle, már kipróbált és jól bevált lehetőségre hívjuk fel mindegyik iskola, de leginkább az egész napos iskolák és a különleges bánásmódot igénylő tanulókat nevelö iskolák figyelmét:

- Az éneknek és a zenének (beleértve az egyszerü hangszeres játékot is) kisgyermekkortól jelentős hatása van a ritmusérzékre, a nyelvi fejlődésre, s ezen keresztül a magasabb szintü megismerő agyi funkciókra. Az eredeti Kodály módszer, valamint a kodályi elveket követő módszerek sokszor bizonyított, közismert pszichológiai, agyfejlődési hatásai szerint a mindennapi közös éneklés, zenélés, tánc beépítése az egész-napos iskola vagy a különleges bánásmódot igénylő tanulókat nevelö iskola napirendjébe fontos kognitív és affektív hangolási funkciót tölt be. A belső érzelemvilág megfelelő hangoltsága teszi lehetővé a hosszútávú memória működését, vagyis a lelki egészség és a tanulás eredményességének egyidejü javulását.

- A különböző alkotó müvészeti és kézmüves tevékenységek a személyes környezet formálásának és az egyéni kibontakozásnak jól ismert alkotóelemei. Beépítésük az egész-napos iskola, valamint a különleges bánásmódot igénylö tanulókat nevelö iskolák napirendjébe, szabad órakeretébe a tanulók egészséges érzelmi és értelmi fejlődéséhez nélkülözhetetlen.

A Kodály-módszer szerinti mindennapi közös énekléshez, zenéléshez a szükséges idő megtalálása mellett még az is fontos feltétel, hogy igen jól képzett, az éneklést-zenélést megszerettető módon tanító énektanára legyen az iskolának.

Az egyéb müvészeti tevékenységek szakkörszerüen müködhetnek, lényeges azonban, hogy lehetőleg mindegyik tanuló vegyen részt ezek valamelyikében, hiszen így érjük el mindegyikük lelki egészségének segítését.

A müvészetek lelki egészséget elősegítő hatásainak eléréséhez az iskolák kiváló külső segítséget kaphatnak a kulturális-közmüvelődési intézmények közösségi alapú lelki egészségfejlesztő tevékenységei által is. A kulturális intézményrendszer több tevékenységével, speciális foglalkozásával és kezdeményezésével is kapcsolódik az iskolai neveléshez.

A lelki egészséget a TIE IV. tevékenysége (Egészség-ismeretek készséggé válást eredményező átadása) is érinti, mivel számos olyan téma (pl. viselkedési függőségek, a szenvedélybetegségekhez vezető szerek fogyasztásának megelőzése, a bántalmazás és iskolai erőszak, depresszió, öngyilkosság megelőzése) feldolgozására kerül sor, mely a tanulók lelki egészségét befolyásolja. Ezek nem helyettesítik, hanem kiegészítik a pedagógusok mindennapi munkáját: a lelki egészséget segítő pedagógiai módszerek folyamatos alkalmazását minden tanulóval.

iv. Egészségismeretek, készségek átadása:

Az egészségismeretek átadásának legbiztosabb módja bizonyára az lenne, ha az egészségtan mint tantárgy jelenne meg az iskolák életében. Erre jelenleg nincs lehetőség, de arra van, hogy az iskolák a pedagógiai programjukban tervezzék meg az egészségismeretek beépítését az 
egyes évfolyamok tanulmányi rendjébe úgy, hogy az iskolából kikerülők végül minden témában felkészültek legyenek - hiszen mai civilizált életünkben ez jelenti a „non scholae, sed vitae discimus" elv megvalósulását.

Az alábbi témalista feldolgozásához aktív együtt- és közremüködést javasolt kialakítani az iskola-egészségügyi ellátás szakembereivel, különös tekintettel arra, hogy nekik ezekhez a témakörökhöz kapcsolódó feladatkötelezettségeik vannak. Az iskola-egészségügyi szolgálaton keresztül igénybe vehetők az Országos Tisztifőorvosi Hivatal országos intézetei, valamint a Megyei Kormány-hivatalok Népegészségügyi Főosztályainak egészségfejlesztő, egészségnevelő munkatársai is (Budapesten a Fővárosi Kormányhivatal kerületi hivatalainak népegészségügyi osztályainak munkatársai).

Egészséget befolyásoló tényezők:

- Az egyén és az őt körülvevő közösség egészsége, mint közös felelősségünk.

- A jó egészségi állapot megőrzése.

- Személyi higiénia.: http://www.e-bug.eu/

- Az egészséges pszichoszexuális fejlődés.

- A környezet egészsége. http://www.okoportal.hu/wpcontent/uploads/2014/06/OGYEI_kiadvany_vedonoknek_A5_PRINT.pdf

- www.antsz.hu

- www.okbi.hu

- www.oek.hu

- www.egeszseg.hu

- www.ogyei.hu

- http://efrirk.antsz.hu/oki/index.html

- www.ogyei.gov.hu/oeti

- www.hazipatika.com

- www.lelekbenotthon.hu

- www.szivbarat.hu

- www.eduvital.hu

- www.futanet.hu

- www.zoldpont.hu

- www.magyar.sport.hu

- www.mozgasvilag.hu

- http://www.dohanyzasvisszaszoritasa.hu/index.html

- www.tudatosvasarlo.hu

- www.okoszolgalat.hu

- www.humusz.hu

- www.levego.hu

- www.okoiskola.hu

- A média egészséget meghatározó szerepe.

- Médiatudatosság, a médiafogyasztás egészségvédő módja.

- Kósa Éva: Gyerekek, serdülők és a média. in: Vajda,Zs. - Kósa,É.: Neveléslélektan. Osiris Kiadó, Bp. 2005.363- 432.o.

- http://nmhh.hu/dokumentum/3840/dontsokosanavilaghalon_web.pdf

- http://buvosvolgy.hu/cikk/118/Kiadvanyok

- http://www.mediatudor.hu/tananyag-form.php

- Müvészeti tevékenységek lelki egészséget, egészséges személyiségfejlődést és tanulási eredményességet elősegítő hatásai. Somhegyi A: A müvészetek, az iskolai egészségfejlesztés és a tanulási eredményesség. Mester és Tanítvány, 2009; 24:29-37. 
https://btk.ppke.hu/uploads/articles/6694/file/24.pdf - (ezt a linket be kell másolni a keresőbe, akkor megnyílik)

- Fogyasztóvédelem, egészségtudatos vásárlóvá válás.

- Idő és az egészség, alvás és egészség, bioritmus, időbeosztás.

- Tartós egészségkárosodással élő társakkal együttélés, a segítségre szorulók segítése.

- Táplálkozás:

- A táplálkozás és az egészség, betegség kapcsolata.

- Az egészséges táplálkozás, élelmiszerek helyi termelése, helyi fogyasztása.

- Lelki eredetü táplálkozási zavarok.

- A betegek táplálásának sajátosságai.

- Étel-allergia, étel-intolerancia.

- Testmozgás:

- A testmozgás és az egészség, betegség kapcsolata.

- Az egészséghez szükséges testmozgás.

- A szervezet fejlődése és müködése testmozgással és annak hiányában.

- A testmozgás lelki egészséget, egészséges személyiségfejlődést és tanulási eredményességet elősegítő hatásai.

- Lelki egészség (ide tartozik, valamint az agresszió, bántalmazás és a szenvedélybetegségek elsődleges megelőzése is):

- A lelki egészség.

- Önismeret, önértékelés, a másikat tiszteletben tartó kommunikáció módjai, ennek szerepe a másik ember önértékelésének segítésében.

- Az érett, autonóm személyiség jellemzői.

- A társas kapcsolatok (ide tartozik a társas kapcsolati készségek /kommunikációs, stressz- és konfliktus-kezelési, problémamegoldási készség/ fejlesztése, valamint a családi életre nevelés is).

- A nő szerepei, a férfi szerepei.

- A társadalom élete, a társadalmi együttélés normái, illem és etika, erkölcs.

- A családi élet - kapcsolat a család tagjai között; közös tevékenységek.

E témakörhöz kapcsolódó hasznos internetes források:

- http://www.ogyei.hu/kamaszok/bevezeto és www.gyermekbantalmazas.hu

- http://holnaphonlap.hu/node/17

- www.mfm-projekt.hu

- www.ateljesszuloielmeny.hu

- Új Pedagógiai Szemle, 2011/1-5. szám, „Családi életre nevelés az iskolában” tanulmányok, http://epa.oszk.hu/00000/00035/00145/pdf/

- Mester és tanítvány 27.szám, 2010. augusztus, Család és ifjúság rovat tanulmányai. Web: https://btk.ppke.hu/uploads/articles/6694/file/27.pdf

- Betegségek megelőzése:

- Megelőzhető fertőző betegségek, kötelező védőoltással megelőzhető fertőző betegségek, a megelőzés elmulasztásának következményei. www.antsz.hu és www.oek.hu

- Krónikus nem-fertőző betegségek.

- Krónikus betegek jó életminősége.

- Gerincvédelem, gerinckímélet.: http://gerinces.hu/2015/08/12/gyermekeinkgerince-mit-tegyen-a-szulo/

- Balesetek, baleset-megelőzés, elsősegély-nyújtás. 
- A szenvedélybetegségek és megelözésük (dohányzás, kábítószer- és túlzott alkoholfogyasztás, játék-szenvedély, internet- és tv-függés)

- Depresszió megelőzése, felismerése.

Betegségek megelőzéséhez kötődő linkek:

- http://balesetmegelozes.ogyei.hu/index.php;

- http://www.kozlekedes-biztonsag.hu/;

- http://www.napofilm.net/hu/napo-for-teachers;

- http://www.baleset-megelozes.eu/cikk.php?id=893 ; http://www.traff.hu/

- A gyermek fejlődése:

- A gyermekáldás, a várandósság alatti hatások a gyermek fejlődésére.

- A gyermek fejlödését elösegítő hatások a családban, az iskolában.

- Az egészségügy igénybevétele:

- Otthoni betegápolás.

- Iskola-egészségügy igénybevétele.

- Az egészségügyi ellátórendszer további elemeinek igénybevétele.

További hasznos segítségek az egészségtémák feldolgozásához:

- Egészségfejlesztési alapismeretek pedagógusok részére. (Barabás Katalin szerk.: Medicina, 2006)

- Egészségvédelem a közoktatásban. (Aszmann Anna szerk.: Anonymus, 2005)

- Az www.egeszseg.hu honlapon számos egyéb hasznos anyag közt:

- 4_TIE_EPSZA_Higiene_11.pdf

- 5_TIE_EPSZA_Serules_2015_11.pdf

- 6_TIE_EPSZA_Kommunikácio_11.pdf

- Oktatófilmek elérhetőségei

- A lelki egészség fejlesztése, a viselkedési függőségek, a szenvedélybetegségekhez vezető szerek fogyasztásának megelőzése

- A lelki egészség védelmét és fejlesztését célzó iskolai egészségfejlesztési program

- A bántalmazás és iskolai erőszak megelözése

- Iskolai szerfogyasztást megelőző program - Alkoholfogyasztást megelőző iskolai program

- Családi életre nevelés és pszichoszexuális fejlődés

- Az egészséges pszichoszexuális fejlődést támogató iskolai egészségfejlesztési program

- Sérülés-megelőzés és elsősegélynyújtás

- Modellprogram baleset-megelőzésre és elsősegély-nyújtásra iskolákban

- Személyi higiéné

Az www.eduvital.hu honlapon összegyüjtött tartalmak:

- Élet és Tudomány - Egészség = EGÉSZ-ség? c. Eduvital rovat letölthető cikkei (http://eduvital.net/index.php/hu/gyujtemeny/dokumentumok/88-elet-es-tudomany)

- Biológiai háttéranyag letölthető dokumentumai (http://eduvital.net/index.php/hu/gyujtemeny/dokumentumok/161-biologiaihatteranyag)

- Az Eduvital szakértőinek heti interjúi a Kossuth rádió Közelről c. müsorában (http://eduvital.net/index.php/hu/gyujtemeny/audio-video/168-kozelrol) 
- Edukációs kisfilmek (http://eduvital.net/index.php/hu/gyujtemeny/audio-video/199kisfilmek)

- Sokszínű Egészségtudatosság - Értsd, Csináld, Szeresd (szerk. Dr. Falus András és Melicher Dóra) címü, ingyenes terjesztésü könyv (http://eduvital.net/index.php/hu/eduvital-muvek)

Az egyes témák feldolgozásában az iskola-egészségügyi szolgálat szakemberei tudnak a legtöbbet segíteni.

Fontos hangsúlyozni, hogy a témalista több eleme a tanulók lelki egészségét fejlesztő, kiscsoportos foglalkozások formájában dolgozható fel legjobban. Ha az iskola pedagógusainak ebben nincs jártassága, akkor szükségessé válhat megfelelő szakember bevonása, pl.: iskola-orvos, védőnő, pszichológus vagy mentálhigiénikus, szociális segítő (ha van mentálhigiénikus végzettsége is). A szociális segítők iskolai munkáját az illetékes ágazatok a közeljövőben tervezik elöírássá és ezáltal finanszírozottá tenni.

A témalista számos eleme feldolgozásához az iskola-egészségügyi szolgálat vagy a megyei/fővárosi kormányhivatalok népegészségügyi főosztályainak/osztályainak jóváhagyásával és közremüködésével hívhatja, felkérheti az iskola a téma szerinti szakembert segítségül (pl. bőrgyógyászt a melanoma kockázat-csökkentés témájához, nőgyógyászt ill. urológust az egészséges szexuális neveléshez és a szexuálisan terjedő fertőző betegségek (szifilisz, HPV, stb.) megelőzéséhez, a családi életre nevelésben jártas orvost, védőnőt, pedagógust, a családvédelmi szolgálat szakemberét, elsősegély-nyújtás témájához mentőtisztet, mentőorvost, Vöröskereszt-aktivistát, stb.). A külső segítő szakember igénybe vétele bizonyos érzékenyebb témák feldolgozásában azért is hasznos lehet, mert a tanulók egy idegennek bátrabban tehetik fel kérdéseiket, illetve ezáltal megismerik, hogy mely szakemberekhez fordulhatnak probléma esetén. Fontos, hogy e téma-feldolgozás mindegyik tanuló részvételével történjen, mert ha a tanulókra bízzuk a részvételt, épp a leginkább rászoruló tanulók maradnak távol. A segítő szakemberek sok esetben szívességből is elmennek az iskolába (pl. mert szülő vagy barát). Mai társadalmunkban e szívességböl történő segítségnyújtás erősítendő, bátorítandó, mert az anomiának nevezett, lelki egészségünk ellen ható tényezőt javíthatjuk ezáltal. Amennyiben a segítő szakember igénybe vétele forrásbevonást igényelne, javasolt, hogy az iskolák kísérjék figyelemmel és vegyék igénybe az ezt támogató esetleges pályázatokat.

Itt szükséges említést tenni a kívülről bevitt prevenciós programokról is, melyekre valószínűleg még szükség lesz egy ideig, de a TIE abba az irányba hat, hogy az iskolák az egészségfejlesztéshez nem külső programot vesznek igénybe, hanem azt beépítik az iskolai mindennapi életbe, a pedagógiai munkába, és emellett - a fentiekben írtak szerint - egyes témák feldolgozásához segítő szakembert hív(hat)nak.

A TIE 4 alaptevékenységét 3 kiegészitő feladat teszi teljessé: az iskola tárgyi és lelki környezetének egészséget szolgáló alakitása, a szakmai segítség keresése és elfogadása, valamint a nyomonkövetésben való részvétel.

\section{Konklúziók}

A TIE 2012 óta minden köznevelési intézmény részére elöírás hazánkban, ami nagy eredmény, hiszen az EVSZ fő ajánlását sikerült gyakorlatba ültetnünk: az egészségügy és a köznevelés együttmüködését. Természetesen az elöírás önmagában még kevés: az egészségügynek még nagyon sok segítséget kell nyújtania az iskoláknak, hogy ők a TIE-t minél jobban meg is tudják valósítani.

Most, amikor a Köznevelési Kerekasztal müködése során a köznevelés közös újragondolása van éppen folyamatban és minden szereplő a gyermekek jobb, eredményesebb, sikeresebb 
oktatását és nevelését szeretné elérni, az orvos örül: hiszen mindenki arról beszél, amit az orvos szeretne. A pedagógus azt mondja: érdeklődő, motivált, jól nevelt gyerekeket szeretne tanítani - az orvos ugyanezt úgy hívja: a gyerek lelki egészsége. A pedagógusok szívükben viselik a közös célt és amikor a pedagógiai módszerek megújításáról beszélnek, akkor a TIE III. feladatáról gondolkoznak, vagyis a gyerekek lelki egészségét szolgáló pedagógiai módszerekről. Bízom abban, hogy a mostani nekibuzdulás eredményes lesz: a pedagógusok képzésében és továbbképzésében megjelennek és elterjednek, sőt gyakorlattá is válnak a lelki egészséget szolgáló pedagógiai módszerek.

Így a pedagógusok részére a mostaninál is kézenfekvőbb lehet saját szerepük és felelősségük a rájuk bízott gyermekek és fiatalok jobb testi-lelki-szellemi egészsége, vagyis jobb boldogulása elérésében.

\section{Irodalom}

Barabás, K. (szerk.) (2006). Egészségfejlesztés - Alapismeretek pedagógusok számára. Medicina, Budapest

Benkő, Zs. (2010). Egészségfejlesztés a közoktatásban és a tanárképzésben. Népegészségügy, 88:37-42.

Conference report (2002). Education and health in partnership. A European conference on linking education with the promotion of health in schools. Egmont aan Zee, 2002. szeptember 22-27. International Planning Committee (IPC) (ISBN: 90-72796-07-2.)

Csermely, P., Fodor, I., Joly, E., Lámfalussy, S. (2009). Szárny és teher - Ajánlás a nevelésoktatás rendszerének újjáépitésére és a korrupció megfékezésére, Bölcsek tanácsa Alapítvány.

Fábián, R, Simich, R. (2006). Meglévő és müködö modellprogramok, valamint az iskolai szexedukációs események értékelése. OEFI, Budapest

Hoffmann, R. (2006). Köznevelésünk ma és holnap. Mester és Tanítvány, 9:10-50.

Hoffmann, R. (2009). Iskola - Erkölcs - Tudás. A köznevelési, szakképzési, felősoktatási és felnőttképzési rendszer újjáépítése. Barankovics István Alapítvány, Budapest.

Net1: Teljes körü iskolai egészségfejlesztési koncepció. TÁMOP-6.1.2.A-14/1. (Letöltés: 2016. november 2. Web:

http://projektek.egeszseg.hu/documents/17618/2222750/Teljes+k\%C3\%B6r\%C5\%B1+Isko lai+Eg\%C3\%A9szs\%C3\%A9gfejleszt\%C3\%A9s+Koncepci\%C3\%B3.pdf/9bd631f4-b0274802-8cec-3e343f29c5fe?version=1.0).

Net2: Physical education in schools - both quality and quantity are important. A statement from the American Cancer Society, the American Diabetes Association, and the American Heart Association on physical education. (Letöltés: 2016.09.22. Web:

www.everydaychoices.org , azon belül: file:///C:/Users/somhegyi/Downloads/FactsPhysical\%20Education\%20in\%20Schools.pdf).

Net3: Quality dayly physical education. PHE Canada's position statement on quality dayly physical education. (Letöltés: 2016.09.22. Web: http://www.phecanada.ca/programs/quality-daily-physical-education).

Net4: Centers for Disease Control and Prevention, USA: Healthy youth - student health and academic achievement. (Letöltés: 2016.09.22. Web: http://www.cdc.gov/HealthyYouth/health_and_academics/index.htm).

Net5: Schools for Health (SHE) honlapja. (Letöltés: 2016.09.22. Web: http://www.schoolsfor-health.eu/she-network).

Net6: I. Young, L. St Leger, G. Buijs (2013). School health promotion: evidence for effective action. Background paper SHE Factsheet 2. (Letöltés: 2016.09.22. Web: 
http://www.schools-for-health.eu/uploads/files/SHE\%20Factsheet_2_Background\% 20paper_School\% 20health\%20promotion_Evidence.pdf).

Net7: Jeffrey, L. Charvat (2012). Research on the relationship between mental health and academic achievement. (Letöltés: 2016.09.22. Web: http://www.nasponline.org/Documents/Research\%20and\%20Policy/Research\%20Center/A cademic-MentalHealthLinks.pdf).

Net8: Suldo, M.M., Gormley, M.J., DuPaul, G.J., Anderson-Butcher, D. (2014). The impact of school mental health on student and school-level academic outcomes: current status of the research and future directions. School Mental Health, DOI: 10.1007/s12310-9116-2. (Letöltés: 2016.09.22. Web: www.researchgate.net/publication/262571894).

Net9: WHO Regional Office for Europe (2014). Health 2020: education and early development. Synergy between sectors: Fostering better education and health outcomes. (Letöltés: 2016.09.22. Web: http://www.euro.who.int/_data/assets/pdf_file/0004/257881/H2020-SectoralBriefEducation_11-09-Eng.pdf).

Net10. WHO Regional Office for Europe (2001). Urban and peri-urban food and nutrition action plan. (Letöltés: 2016.09.22. Web: http://www.euro.who.int/_data/assets/pdf_file/0016/101626/E72949.pdf?ua=1).

Net 11. A Nemzeti Együttmüködés Programja. 2010. május 22. (Letöltés: 2016.09.22. Web: http://www.parlament.hu/irom39/00047/00047.pdf).

Net12. Az egészség aTIEd is! A teljeskörü iskolai egészségfejlesztés tevékenységei. Ajánlás a pedagógusok részére. (Letöltés: 2016.09.22. Web: http://www.kormany.hu/hu/dok? source=2\&type=402\#! DocumentBrowse).

Net13. Physical activity strategy for the WHO European Region 2016-2025. (Letöltés: 2016.09.22. Web: http://www.euro.who.int/_data/assets/pdf_file/0010/282961/65wd09e_PhysicalActivityStr ategy_150474.pdf?ua=1).

Net14. A biomechanikailag helyes testtartás kialakítását, automatizálását és fenntartását szolgáló speciális tartáskorrekció. (Letöltés: 2016.09.22. Web: http://gerinces.hu/prevencio/tartaskorrekcio-konyv-es-dvd-csak-gerincesen/).

Paksi, B. (2009). Felmérés a közoktatás rendszerében alkalmazott prevenciós/egészségfejlesztö programokról és az agresszióval kapcsolatban megjelenö vélekedésekröl, reagálásokról. Kutatási beszámoló, Budapest

Pusztai, Zs. (2011). Az egészség társadalmi meghatározói és az egyenlőtlen egészség európai áttekintése az EVSZ Európai Régiójában. Népegészségügy, 89:147-150.

Somhegyi A. (2012). A teljeskörü iskolai egészségfejlesztés országos megvalósítását elösegítő elemek a nemzeti köznevelésről szóló 2011. évi CXC törvényben. Népegészségügy, 90(3):202-213.

Somhegyi A. (2014). A mindennapi testnevelés egészségfejlesztési kritériumai: megvalósításuk jelen helyzete. Népegészségügy; 92:4-10.

Somhegyi, A. (2006). Egészségnevelés és egészségfejlesztés a közoktatásban. Mester és Tanítvány, 10: 82-90.

Somhegyi, A. (2009). A müvészetek, az iskolai egészségfejlesztés és a tanulási eredményesség. Mester és Tanítvány, 24:29-37.

Somhegyi, A. (2010). Egészség az iskolában - A sikeres oktatás-nevelés kulcsa. Új Katedra „Nevelés” különszáma, III:20-29

Somhegyi, A., Tóth, J., Makszin, I., Gardi Zs., Feszthammer A., Darabosné Tim I., Tóthné Steinhausz V., Tóthné Szabó K., Varga P. (2005). A Magyar Gerincgyógyászati Társaság 
primaer prevenciós programja II. - A tartásjavító mozgásanyag kontrollált prospektív vizsgálata. Ideggyógyászati Szemle 58(5-6):177-182. (Web: www.ogk.hu).

Stewart-Brown, S. (2006). What is the evidence on school health promotion in improving health or preventing disease and, specifically, what is the effectiveness of the health promoting schools appoach? Copenhagen, WHO Regional Office for Europe (Health Evidence Network report). (Letöltés: 2016.09.22. Web:

http://www.euro.who.int/document/e88185.pdf).

Symons, C., Cincelli, B., James, T.C., Groff, P. (1997). Bridging student health risks and academic achievement through comprehensive school health program. Journal of School Health, 67:6, 220-227 (Web: www.ogk.hu). 